\title{
Program Peningkatan Kesehatan Ibu dan Anak Melalui Dukungan Kegiatan Posyandu
}

\author{
Hafnidar $^{1 *}$, Cut Ita Zahara ${ }^{1}$, Rahmia Dewi ${ }^{1}$, Ikhyanuddin ${ }^{2}$ \\ Published online: 5 July 2021
}

\begin{abstract}
Posyandu activities need to get support from all parties. Posyandu aims to support government programs in improving the health status of the community, especially mothers and children. Posyandu activities are organized by village midwives and help by village cadres. Without the support of all parties including stakeholders and the beneficiary community, Posyandu activities are difficult to succeed. This program includes the provision of standard posyandu equipment, the provision of educational game facilities for children, additional feeding, and health promotion. Program activities are carried out through a number of strategies. Finally, the success and sustainability of the program on the support of all parties.
\end{abstract}

Keyword: Health, Mother and Child, Posyandu

\begin{abstract}
Abstrak. Kegiatan Posyandu perlu mendapat dukungan dari semua pihak. Posyandu bertujuan untuk mendukung program Pemerintah dalam peningkatan status kesehatan masyarakat khususnya Ibu dan anak. Kegiatan Posyandu diselenggarakan oleh Bidan desa, dan beberapa orang Kader desa. Tanpa dukungan semua pihak termasuk pemangku kepentingan dan masyarakat penerima manfaat, kegiatan Posyandu sulit berhasil. Program pengabdian ini meliputi penyediaan peralatan standar posyandu, penyediaan sarana permainan edukatif untuk anak, pemberian makanan tambahan, dan penyuluhan kesehatan. Program kegiatan dilakukan melalui sejumlah strategi. Akhirnya, keberhasilan dan keberlanjutan program atas dukungan kerjasama semua pihak.
\end{abstract}

Kata kunci: Kesehatan, Ibu dan anak, Posyandu

\section{PENDAHULUAN}

Pos Pelayanan Kesehatan Terpadu disingkat Posyandu merupakan posko kesehatan di desa untuk ibu hamil dan anak di bawah lima tahun. Posyandu merupakan wadah dimana masyarakat memperoleh pelayanan kesehatan dasartermasuk pemeliharaan dan perawatan ibu dan anak (Depkes RI, 2011). Posyandu di Provinsi Aceh dilaksanakan sebulan sekali, masih berjalan khususnya di daerah hijau pandemi Covid19 seperti di

${ }^{1}$ Program Studi Psikologi, Fakultas Kedokteran, Universitas Malikussaleh

${ }^{2}$ Fakultas Ekonomi dan Bisnis, Universitas Malikussaleh

*) corresponding author

Hafnidar

Email: hafnidar@unimal.ac.id
Kecamatan Nisam Antara Kabupaten Aceh Utara. Posyandu dilakukan oleh bidan desa dan dibantu oleh tiga hingga lima kader kesehatan desa yang direkrut dari desa. Sebagian besar peralatan Posyandu telah dipasok oleh Dinas Kesehatan Kabupaten Aceh Utara, 
seperti bobot bayi, bobot ibu hamil, kartu sehat, peralatan untuk suplemen makanan masak, bobot ibu hamil dan meteran tekanan darah, modul untuk kampanye kesehatan. Namun demikian, peralatan Posyandu masih belum lengkap, pemeriksaan kehamilan di ruang terbuka Gedung Aula ataupun Mushalla yang disebut Meunasah, tanpa privasi. Ada kebutuhan untuk tirai, kasur, dan bantal untuk cek kehamilan dan ruang observasi di gedung Posyandu.

Meskipun ada 5 kader kesehatan untuk setiap desa yang membantu bidan desa untuk melakukan kegiatan posyandu, kampanye kesehatan bagi masyarakat desa, dan penyediaan suplemen makanan untuk ibu hamil dan anak di bawah lima tahun, namun pemahaman masyarakat desa tentang kesehatan dasar dan bagaimana mencapai hidup sehat masih kurang. Ada sebagian masyarakat penduduk desa yang masih percaya pada mitos tradisional yang dipercayai turun temurun antar generasi, seperti bayi tidak memerlukan vaksinasi karena akan membuat mereka mati, anak-anak tidak boleh mengkonsumsi banyak ikan karena akan membuat mereka menderita cacing, tidak ada suplemen makanan yang dibutuhkan oleh ibu hamil dan hanya dibutuhkan oleh pria sebagai kepala rumah tangga.

Kapasitas kader kesehatan desa yang rendah untuk mempromosikan kesehatan, tidak bisa banyak membantu memperbaiki situasi ini. Kader kesehatan telah beberapa kali mendapatkan pelatihan kesehatan dasar dari Klinik Kesehatan Kecamatan (Puskesmas). Namun demikian, pelatihan yang diberikan tidak memadai untuk membekali mereka dengan keterampilan kesehatan dasar yang diperlukan. Pentingnya Kader memiliki pengetahuan, sikap dan latihan praktik dalam pelaksanaan Posyandu (Latif, 2012).

Di setiap desa, ada satu bidan yang ditugaskan pemerintah untuk memantau kesehatan ibu hamil dan anak di bawah lima tahun dan melaksanakan kampanye kesehatan dalam rangka meningkatkan kesadaran masyarakat desa tentang bagaimana mencapai hidup sehat melalui perilaku sehari-hari mereka. Kampanye kesehatan menyasar seluruh anggota rumah tangga., khususnya kepala rumah tangga. Saat ini, karena pengetahuan kesehatan dasar mereka yang terbatas, manusia sebagai kepala rumah tangga tidak dapat mendorong anggota keluarga, terutama ibu hamil dan anak-anak di bawah lima tahun untuk mendapatkan akses kesehatan yang lebih baik. Akibatnya, beberapa masalah kesehatan meningkat, seperti meningkatnya jumlah anak dibawah lima tahun yang meninggal, banyaknya jumlah anak yang menderita kekurangan gizi, epidemi demam berdarah, kasus diare, kematian ibu dan anak.

Oleh karena itu, tujuan dari program ini adalah untuk meningkatkan kesehatan keluarga khususnya ibu dan anak melalui penyediaan peralatan standar posyandu, pemberian makanan tambahan, dan penyuluhan kesehatan termasuk Teknik komunikasi teurapeutik dalam keluarga.

\section{BAHAN DAN METODE}

Sebelum pelaksanaan kegiatan, terlebih dahulu dilaksanakan rapat sosialisasi dengan semua stakeholder dan pihak-pihak terkait. Tujuannya adalah untuk memberitahukan rencana kegiatan, mengkoordinasikan jadwal kegiatan, perizinan serta menyepakati kontribusi masing-masing pihak seperti kader desa, bidan desa, aparatur desa dan Dinas Kesehatan setempat. Selanjutnya pelaksanaan kegiatan dilakukan sesuai dengan jadwal rencana kerja yang telah disepakati bersama. Terakhir diadakan pula kesepakatan adanya pemantauan dari pemangku kepentingan yang berbeda untuk memastikan keberlanjutan aktivitas serta evaluasi bersama, seperti yang ditunjukkan pada diagram 1 berikut ini: 


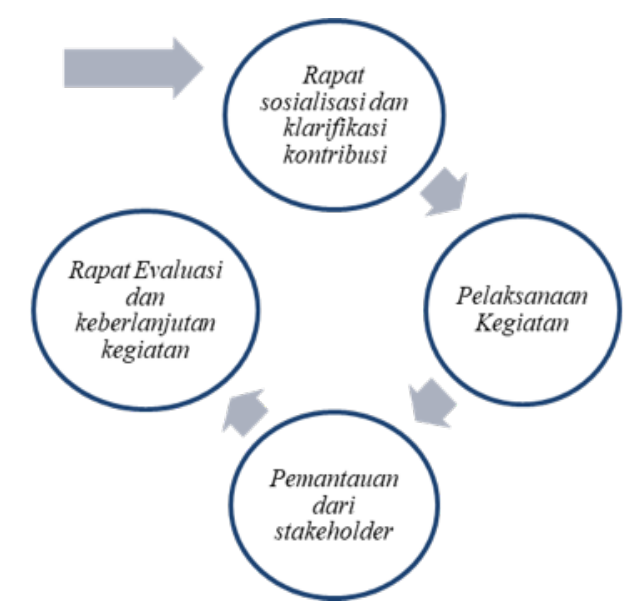

Gambar 1. Diagram Strategi Pelaksaan Program

\section{HASIL DAN PEMBAHASAN}

Program peningkatan kesehatan Ibu dan anak melalui dukungan kegiatan Posyandu dilakukan melalui penyediaan peralatan standar posyandu, penyediaan sarana permainan edukatif untuk anak, pemberian makanan tambahan, dan penyuluhan kesehatan, seperti yang diuraikan berikut ini:

\section{Penyediaan Peralatan Posyandu}

Penyediaan Peralatan Posyandu sangat diperlukan masyarakat desa. Jika peralatan posyandu lengkap, pemeriksaan kesehatan ibu hamil akan lebih baik dan berdasarkan standar nasional. Peralatan yang diberikan adalah timbangan ibu hamil, timbangan anak-anak di bawah lima tahun (balita), timbangan bayi, permainan edukatif, penutup tirai, kasur, bantal, papan nama posyandu, brosur atau lembar jadwal konsultasi posyandu. Peralatan yang akan diberikan untuk desa melalui kepala desa, disimpan oleh kader dan bidan desa. Status kesehatan ibu hamil akan membaik dengan meminimalisir risiko hamil dan melahirkan. Dengan menyediakan peralatan standar ibu hamil akan menarik untuk mengunjungi posyandu.
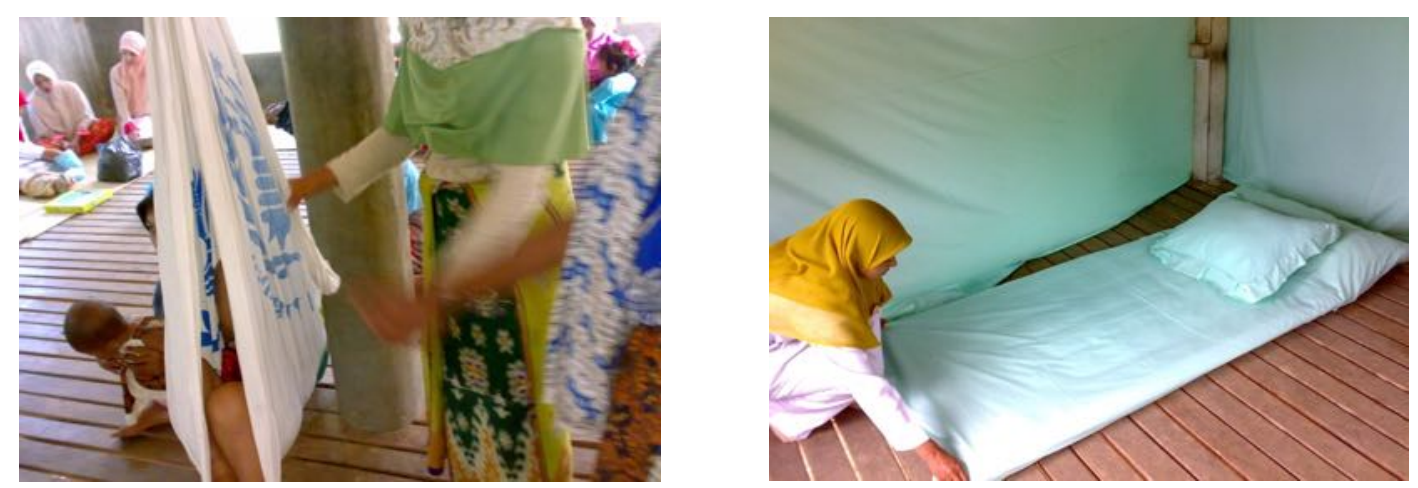

Gambar 1. Beberapa Perlengkapan Posyandu

\section{Penyediaan Permainan edukasi}

Penyediaan permainan edukasi, akan menarik dan menghibur anak-anak, orangtua pun akan belajar cara mendampingi anak bermain secara sehat dari kegiatan yang dilakukan oleh kader desa pada saat kegiatan Posyandu berlangsung. 


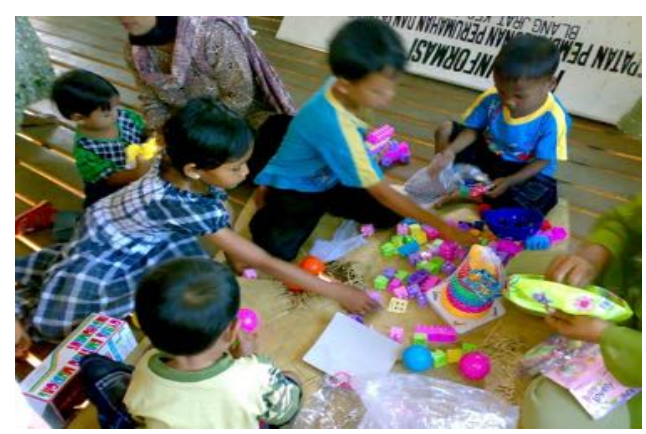

Gambar 2. Anak-anak bermain Bersama di Posyandu

\section{Penyuluhan dan penyediaan brosur Posyandu}

Brosur Posyandu bermanfaat untuk meningkatkan pengetahuan masyarakat tentang kesehatan ibu dan anak. Manfaatnya juga akan didapatkan oleh orang atau tetangga lainnya yang tidak wajib datang ke Posyandu.

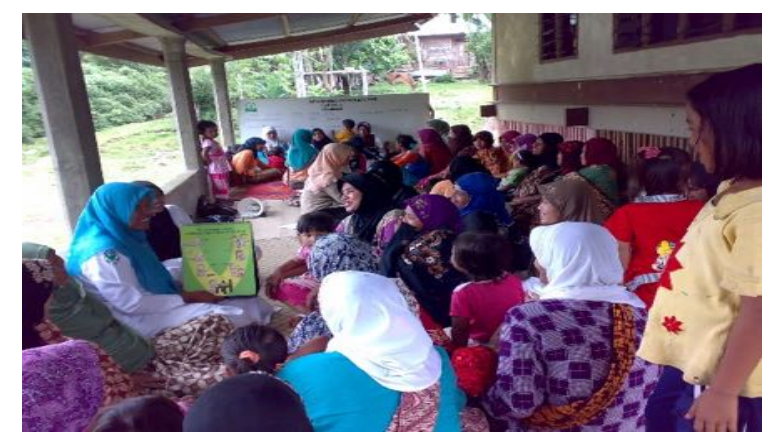

Gambar 3. Penyuluhan Kesehatan

\section{Program makanan tambahan}

Program makanan tambahan digunakan untuk mendukung peningkatan pemenuhan nutrisi anak. Disamping itu, makanan tersebut akan digunakan untuk membuat masyarakat terbiasa dalam memberikan makanan bergizi bagi anak-anak. Kegiatan tersebut juga dilakukan melalui penyuluhan makanan sehat oleh kader posyandu untuk masyarakat, yang materi dimulai dari pengenalan makanan dan kandungan gizi, cara pengolahan dan penyajian (Kosasih, Isabella, \& Sriati, 2012). Program makanan tambahan juga dapat meningkatkan daya tarik masyarakat untuk mengunjungi posyandu.

Disamping itu, ketersediaan makanan tambahan akan terus diupayakan kader desa melalui program swadaya masyarakat di desa. Setiap pengunjung Posyandu akan memberikan kontribusi berdasarkan kesepakatan. Hal itu dilakukan dalam rangka menjaga stabilitas kegiatan posyandu meskipun tidak ada bantuan dari luar.

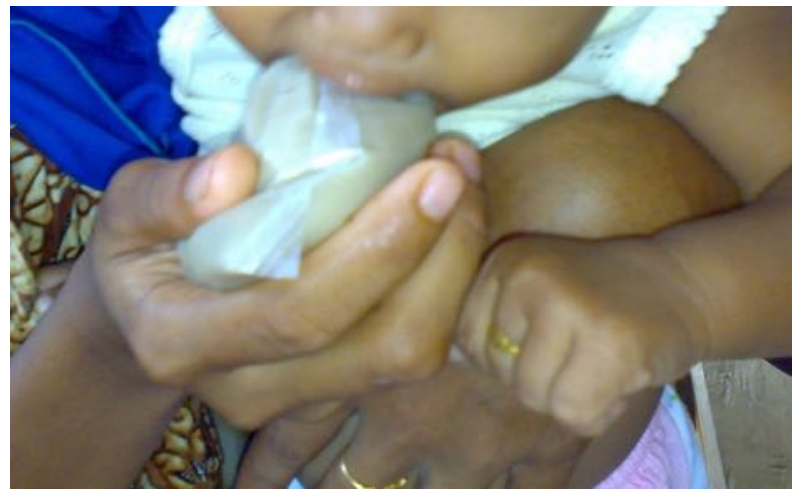

Gambar 4. Program makanan tambahan di Posyandu 
Keberhasilan suatu program salah satunya karena ada dukungan Lembaga terkait dan masyarakat penerima manfaat (Muda, Hariyanto, \& Ardiyani, 2017). Dinas Kesehatan Aceh Utara memberikan dukungan dan kontribusi untuk memastikan kelancaran program dengan penyediaan pelatihan kesehatan kepada penyuluh kesehatan di lapangan, penyediaan materi pelatihan kesehatan dan tempat pelatihan.

Sementara itu, Bidan desa memberikan dukungannya dengan menyiapkan makanan tambahan melalui kader desa, pemberian bantuan dan monitoring bagi kader kesehatan desa dan penyiapan tempat promosi kesehatan dan kegiatan kampanye oleh aparatur desa dibantu kader desa. Selain itu, kontribusi kader kesehatan desa dalam mensosialisasikan kegiatan Posyandu kepada masyarakat desa dan penyiapan makanan tambahan dari sumbangan dana donator tetap dan tidak tetap.

Kader dan aparatur desa memberikan dukungan yang signifikan terhadap program kegiatan ini. Kader yang telah mendapatkan pembekalan pengetahuan dan pelatihan ketrampilan, dapat berkontribusi maksimal terhadap suatu kegiatan (Sandiyani \& Mulyati, 2011). Akhirnya keberlanjutan program tetap mendapatkan pemantauan dari Dinas Kesehatan Aceh Utara.

\section{KESIMPULAN DAN SARAN}

Dukungan terhadap kegiatan Posyandu perlu dilakukan semua pihak khususnya stakeholder pemangku kepentingan dan masyarakat penerima manfaat, demi meningkatkan status kesehatan Ibu dan anak. Program peningkatan kesehatan ibu dan anak ini dilakukan melalui penyediaan peralatan standar Posyandu, pemberian makanan tambahan kepada balita, promosi kesehatan dan kampanye kepada masyarakat desa. Kegiatan ini dilakukan melalui sejumlah strategi demi keberhasilan dan keberlanjutan program yaitu dimulai dari rapat sosialisasi dan klarifikasi kontribusi masing-masing pihak, pelaksanaan kegiatan, pemantauan kegiatan serta rapat evaluasi serta kesepakatan penanggungjawab keberlanjutan kegiatan.

\section{UCAPAN TERIMAKASIH}

Penulis mengucapkan terima kasih kepada Lembaga Pengabdian Pada Masyarakat (LPPM) Universitas Malikussaleh, Lembaga Swadaya Masyarakat Community Care of Humanity (LSM $\mathrm{CCH}$ ), Dinas Kesehatan Kabupaten Aceh Utara, Aparatur desa dan seluruh masyarakat yang berpartisipasi aktif dalam kegiatan ini.

\section{Conflict of Interests}

The authors declared that no potential conflicts of interests with respect to the authorship and publication of this article.

\section{DAFTAR PUSTAKA}

Depkes RI. (2011). Pedoman Umum Pengelolaan Posyandu. Jakarta, Kementrian Kesehatan RI. Kosasih, C. E., Isabella, C., \& Sriati, A. (2012). Upaya peningkatan gizi balita melalui pelatihan kader kesehatan. Jurnal Media Karya Kesehatan, 1(1), 90-100. 
Latif, RVN. (2012), Hubungan Faktor Predisposing Kader (Pengetahuan dan sikap Kader terhadap Posyandu) dengan Praktik kader dalam Pelaksanaan Posyandu di wilayah Kerja Puskesmas Wonokerto: Fakultas Ilmu Kesehatan Universitas Pekalongan.

Muda, M. H., Hariyanto, T., \& Ardiyani, V. M. (2017). Hubungan Dukungan Keluarga dengan Motivasi Lansia dalam Mengikuti Kegiatan Posyandu Lansia di Kelurahan Tlogomas Kecamatan Lowokwaru Malang. Nursing News: Jurnal Ilmiah Keperawatan, 2(1).

Sandiyani, R. A. \& Mulyati, T. (2011). Pengetahuan Gizi, Sikap, Frekuensi Pelatihan, dan Lama Menjadi Kader dengan Perilaku Penyampaian PUGS. 